UDC 091(=163.41)"16/18"

271.2-722:929 Zelić G

https://doi.org/10.18485/ms_zmskij.2021.69.2.9

Др Моника Фин

\title{
КОНФЕСИОНАЛНА ПОЛЕМИКА У ДАЛМАЦИЈИ У ПРЕПИСЦИ ГЕРАСИМА ЗЕЛИЋА
}

\begin{abstract}
Конфесионална полемика која је између XVII и XIX века супротставила православне Србе и католички клер у северној Далмацији била је предмет бројних историографских студија. У раду се представљају активности истраживачког пројекта посвећеног конфесионалној полемици у Далмацији на основу рукописних докумената везаних за личност српског архимандрита Герасима Зелића, који је најпре био генерални викар Срба у Далмацији (1792-1810), а затим епископски викар за регију Боке которске (1810-1811). Рад описује различите стадијуме пројекта задржавајући се на резултатима до којих је међународни истраживачки тим дошао током две године своје активности.

Кључне речи: конфесионална полемика, Далмација, Герасим Зелић, рукописна грађа, митрополит Стефан Стратимировић.
\end{abstract}

1. Конфесионална полемика која је између XVII и XIX века супротставила православне Србе и католички клер у Тромеђи - делу северне Далмације око којег су се дуго борили Млетачка република, Османско царство и Хабзбуршка монархија - била је предмет бројних историографских студија: радови Никодима Милаша (1901), Мила Боговића (1982), Марка Јачова (1984), Драга Роксандића (2003) и Еђидија Иветића (2009), да споменемо само неке од њих, у значајној су мери омогућили реконструкцију сложеног историјско-културног мозаика овог региона, иако су понекад пружали веома различита тумачења. ${ }^{1}$

Конфесионални елемент представља специфичну различитост на којој је утемељена тешка коегзистенција између хрватског католичког клера и православних Срба (тзв. Морлака) који су се преселили у северни део Дал-

1 За исцрпан преглед литературе и ставове различитих историографских традиција о конфесионалној полемици у Далмацији уп. IVETIC 2009. 
мације након млетачко-турских ратова (1645-1718). Нетолеранција католичког клера према православним Србима у Далмацији огледала се у сукобу интереса представника српске цркве и католичке хијерархије, која је тежила духовном монополу и обнови својих искључивих јурисдикцијских права и над православним поданицима са територија које су недавно освојили Млеци. Тај антагонизам преливао се из црквених сфера и у ниже народне слојеве, где је нарочито био изражен у виду српског православног и римокатоличког верског супротстављања (уп. SARIĆ 2007).

Уз пажњу католичког свештенства, досељеници православне вере морали су да трпе и покушаје интеграције од стране главних европских сила које су биле присутне у региону, тј. Млетачке републике, Наполеонове Француске и Хабзбуршке монархије. За Венецију, на пример, уклапање досељеника у друштвени систем млетачке Далмације није био само локални проблем, него кључна тачка у односима између Републике и православних поданика током читавог осамнаестог века. Научници су често оцењивали понашање млетачких провидура према православним Србима као „осцилирајуће“, или равнодушно: наиме, на конфесионалну политику Венецијанаца снажно су утицале не само историјске околности с којима је Република Св. Марка морала да се суочи, него и „политичке идеје, способност за посредовање, те осетљивост појединиих провидура у Далмацији у односу на конфесионално питање“ (уп. МоRABITo 2001: 282). Много боље дефинисан био је положај Аустријанаца, који су почетком 19. века покренули специфичан пројекат за унијаћење далматинских православаца. Spiritus movens тог пројекта је био цар Франц II. Тим путем Хабзбуршка монархија је такође желела да оконча традиционални утицај руских царева на православне народе Балканског полуострва, који су у Русији видели савезника у борби за ослобођење од стране доминације.

Са своје стране, српска заједница је чврсто бранила своје културно наслеђе и идентитет, тражећи легитимитет за своју цркву у далматинском подручју. Након неколико неуспешних покушаја за време млетачке владавине, далматинска православна епархија је коначно била основана 1809. г. под француском влашћу, те је следеће године са̂м Наполеон именовао Бенедикта Краљевића првим православним епископом за Далмацију. Међутим, оснивање епархије није решило, него можда и повећало тензију између православних Срба и далматинског римокатоличког клера.

У овом контексту „застрашујућег хаоса“ (PALAdin 2002)2 смештен је животни пут српског архимандрита Герасима Зелића (1752-1828). Пореклом из задарског залеђа и човек „Тромеђе“, Зелић је најпре обављао дужност генералног викара далматинских Срба (1796-1810), а потом епископског викара у Котору (1810-1811) поставши један од главних актера догађаја везаних

${ }^{2}$ Израз је преузет од Анђела Диједа (Angelo Diedo) којег је Сенат Млетачке републике именовао за генералног провидура Далмације и Албаније 1789. године и који је по свом доласку управо тако описао земље којима је требало да управља. 
за конфесионалну полемику у Далмацији на прелазу између XVIII и XIX века. Упркос неспорној раскоши личности, до данас нема монографије, или бар систематске студије која би реконструисала јавни живот Герасима Зелића и била у стању да пружи поуздан приказ његовог учешћа у догађајима везаним за конфесионалну полемику: малобројни историографски доприноси посвећени његовом животу углавном су сажетог или фрагментарног карактера. ${ }^{3}$ Осим тога, још увек се у великој мери ослањају на Зелићеву аутобиографију Жийије, која је објављена у Будимпешти $1823 .{ }^{4}$ Управо на том тексту заснивају се ставови, у најмању руку опречни, које је до сада изразила историографија о раду српског архимандрита. ${ }^{5}$

Ова студија ће представити активности истраживачког пројекта под називом The interconfessional polemic between the Orthodox Serbs and the Catholic Church in the manuscripts of Gerasim Zelić, којим се желео дати допринос проучавању конфесионалне полемике у Далмацији на основу једног корпуса рукописних докумената о личности српског архимандрита. ${ }^{6}$ У наредним пасусима описаћемо различите стадијуме пројекта задржавајући се на резултатима до којих је међународни истраживачки тим дошао током две године рада. ${ }^{7}$

${ }^{3}$ Након страница које је Никодим Милаш посветио Зелићу у својој Православној Далмацији (1901) уследила су истраживања Љубомира Влачића, која су се појавила двадесетих и тридесетих година прошлог века, те недавно Персиде Лазаревић ди Ђакомо.

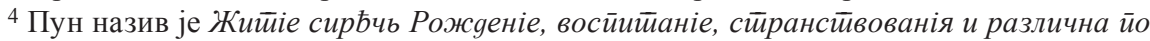

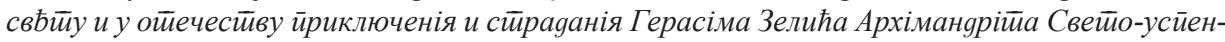

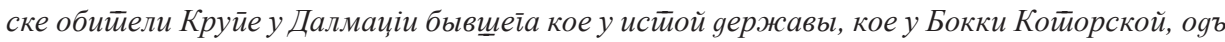
л. 1796 gо кониа л. 1811. наgъ йравославными восточонойа исйовбуанія церквами / Нимъ самымъ

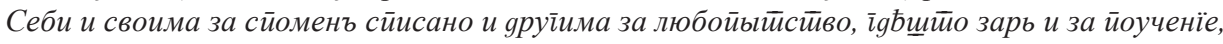

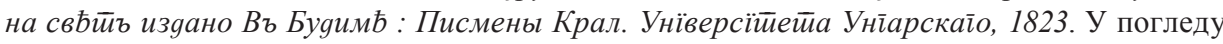
веродостојности, Бошко Ковачек пише: „У аутобиографици није увек потпуно отворен и тачан; најчешће прећуткује оне околности свога живота које би га могле учинити политички сумњивим код власти.“Сличан је и суд Никодима Милаша који реконструишући живот српског архимандрита признаје да је често прибегавао Жийију, али прецизира: „Је ли све овако, како Зелић пише, ми нијесмо у стању процијенити, јер нам оскудјевају за то односни додатци“ (МилАш 20043: 433).

${ }^{5}$ Никодим Милаш, на пример, описује Зелића час као просвећеног свештеника и веома ангажованог у одбрани конфесионалног идентитета православних заједница из своје јурисдикције, час као скоројевића и интриганта, опседнутог влашћу. У истом смеру иде и оцена Љубомира Влачића, који у погледу Зелићевог амбициозног карактера пише да је српски архимандрит „од детињства па до смрти сањао је само о части и власти, о епископској митри““ (ВлАчић 1928: 215).

${ }^{6}$ Пројекат је финансирао Департман за лингвистичке и књижевне студије Универзитета у Падови.

${ }^{7}$ Из пројекта је настао тематски зборник посвећен Зелићу и српској култури његовог времена, под насловом „Gerasim Zelić e il suo tempo“ (уп. Fin - STEEnwIJK 2019). Зборник је 2019. објавила издавачка кућа Firenze University Press уз подршку Департмана за лингвистичке и књижевне студије Универзитета у Падови (Dipartimento di Studi linguistici e letterari, 
2. Пројектна истраживачка активност дотакла је неколико области. Најпре, употпуњена је каталогизација и дигитализација корпуса рукописних докумената који је нађен у Архиву Српске академије наука и уметности у Сремским Карловцима (даље АСАНУК), Рукописном одељењу Библиотеке Матице српске (даље РОМС) и Државном архиву у Задру (даље ДАЗД). Из првобитног корпуса од око 300 докумената, који је садржао укупно више од 1000 рукописних хартија на српском, италијанском, немачком, грчком и латинском, формиран је коначни корпус од 140 докумената који се уско тичу тематике пројекта. Одабрани рукописи покривају временски период од јануара 1794. до септембра 1830. године. Највећи део корпуса чини лична преписка Герисама Зелића, поред бројних докумената млетачких, аустријских и француских власти које су у оно доба наизменично владале Далмацијом.

Већ при првој анализи корпуса испоставило се да је $80 \%$ докумената необјављено, уз изузетак оних који се налазе у првом издању Зелићеве аутобиографије (ЗЕлић 1823). Иста та документа преузео је Никодим Милаш у монографији Православна Далмачија (1901).

Рукописи су дигитализовани применом критеријума конзерваторског типа и у потпуном складу с филолошким критеријумима прихваћеним у међународној научној заједници. Документи су транскрибовани у формату TEI (Text Enconding Initiative), који је посебно погодан за дигиталну транскрипцију докумената који се односе на humaniora јер омогућава да се садржај организује према логичким односима уз употребу обележивача, задржавајући непромењен формат текста. Осим организовања транскрибованог текста у његовом формалном аспекту, обележивачи му дају и својства базе података: могуће је, дакле, извршити претраживање у транскрибованом тексту које увелико превазилази једноставну претрагу стрингова. У случају проучаваног пројекта, процес транскрипције и индексације омогућио је да се спроведу истраживања на прикупљеним документима који су анализирани како с филолошко-лингвистичког, тако и са историјско-културног аспекта. Напослетку, треба подсетити да текст транскрибован у TЕI формату може лако да се конвертује у друге формате (на пример .doc или .pdf), што се показало посебно корисним током деликатног процеса лектуре и коректуре транскрибованих докумената.

У погледу транскрипције рукописа̂ на српском језику, који чине око $70 \%$ корпуса, одлучено је да се текстови на ћирилици транслитерују на латинични алфабет: ову одлуку је наметнула жеља да грађа буде доступна широј јавности. Будући да се ради о документима написаним у епохи која је претходила стандардизацији српског правописа и књижевног језика, одређивање филолошких критеријума ослањало се превасходно на студије Александра Младеновића ${ }^{8}$, као и на дела из раног српског деветнаестог

Università degli Studi di Padova). Књига је доступна и онлајн на сајту самог издавача (https:// fupress.com/catalogo/gerasim-zelic-e-il-suo-tempo/3998).

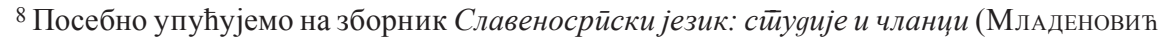
1989). 
века (дакле из истог доба из ког су и проучавани рукописи) која је Матица српска недавно објавила у едицији Језичка башииина. Према томе, све правописне варијације у документима верно су пренете у транскрипцију.

По завршетку транскрипције, направљен је веб сајт посвећен пројекту где је могуће прегледати дигитализоване документе. ${ }^{9}$ Осим с историјско-културног аспекта, прикупљена грађа чини вредан корпус и за анализу лингвистичке врсте, посебно у погледу српског језика предстандардног периода.

3. Сајт пројекта, који се може погледати на линку http://www.maldura. unipd.it/zelic/ приказује пет главних одељака које ћемо укратко описати у наставку.

Насловна страна сајта садржи кратак опис пројекта као и друге садржаје о актуелностима пројекта (The project), о биографији и књижевном делу Герасима Зелића (Zelić and his Žitije), о различитим фазама реализације пројекта (Realisation of the project) као и о досад прикупљеним резултатима (Final conclusions and possible further research). Последњи одељак је посвећен истраживачком тиму и установама које су учествовале у пројекту (Research team and credits). ${ }^{10}$

У одељку под називом Transcriptions налазе се дигитализована документа, поређана према презимену аутора и/или потписника, а на нижем ступњу према датуму. Структура сајта омогућава да се истовремено виде фотографска репродукција оригиналних рукописа и њихов дигитализовани текст. Сваки документ прати кратак опис (Summary) попуњен коришћењем модела Dublin Core. ${ }^{11}$ Опис садржи, редом, примаоца документа, аутора, уредника транскрибованог текста, предмет документа, резиме садржаја, место документа (тј. архиву из које потиче и сигнатура), датум и напослетку идентификациони коิд за сваки документ унутар корпуса.

У случају да се у тексту појављују скраћенице, довољно је мишем прећи преко стринга да би се појавила цела реч. Правописне грешке, које се највише тичу писања имена и презимена, обележене су тагом $<$ sic $>$. На крају, речи око којих постоји недоумица појављују се у транскрипцији у сивој боји.

Као што је већ поменуто, током транскрипције документи су били индексирани према пет главних категорија: <organizations>, <persons>, <places>, $<$ roles $>$ и $<$ subjects $>$. Комплетна листа индекса, подељених у наведених пет категорија, може се погледати у одељку сајта названом Indexes. Процес

${ }^{9}$ Онлајн објављивање докумената је још увек у току.

${ }^{10}$ Међу установама које су омогућиле успех пројекта налазе се већ поменуте АСАНУК, РОМС и ДАЗД, где су спроведена истраживања. Осим њих, посебну захвалност изражавам Библиотеци Матице српске која је дала на увид дигиталну копију првог издања Житиија Герисама Зелића, чије је ишчитавање било неопходно за спроведене анализе у првом делу пројекта.

11 За више информација погледати сајт http://dublincore.org/documents/dces/. 
индексације омогућава кориснику да спроводи унакрсне претраге у документима путем једне веб апликације. Осим тога, кликом на сваки индекс отвара се падајућа листа са свим документима у којима се појављује дати индекс.

Последња два одељка сајта (Studies е Bibliography) садрже, редом, студије настале током две године трајања пројекта и референтну библиографију у којој се налази како грађа о конфесионалној полемици и историји северне Далмације, тако и она о Зелићевој личности и његовој аутобиографији.

4. У закључку ове студије треба истаћи, бар у сажетом облику, резултате до којих је истраживачки тим дошао током две године свог деловања.

У складу с претпоставкама формулисаним на почетку пројекта, анализа прикупљених и дигитализованих рукописа потврдила је велику историјско-културну вредност проучаваног корпуса захваљујући ком је било (и биће) могуће разјаснити неке мање јасне тачке које до сада конфесионална историја северне Далмације није довољно испитала. У оквиру дигитализоване грађе, од посебне су вредности приватна писма Герасима Зелића, који је најпре као генерални викар Срба у Далмацији (1792-1810) а потом као епископски викар за регију Боке которске (1810-1811) одржавао епистоларне односе (и то не увек мирољубиве) с млетачким, аустријским и француским властима, ${ }^{12}$ као и с најеминентнијим црквеним великодостојницима ондашње Српске православне цркве, пре свих карловачким митрополитом Стефаном Стратимировићем.

У погледу садржаја, у корпусу се могу издвојити три главна тематска језгра. Прво обухвата документа који сведоче о сукобу између архимандрита Зелића и Бенедикта Краљевића (1765-1862), ког је Наполеон Бонапарта у марту 1810. године именовао за првог православног епископа у Далмацији. Тада је Зелићу била остављена дужност викара Боке которске, подређен положај у односу на Краљевића што, у стварности, српски архимандрит никад није прихватио. ${ }^{13}$ Није се дуго чекало на прекид њихових односа: casus belli jе било освећење новог православног храма у Котору, свечаност коју је Зелић одржао у децембру 1810. г. без претходне сагласности свог надређеног, који му је то одмах замерио. Од тог тренутка срдачан тон, који је до тог момента био својствен њиховој преписци, постао је крајње опор, посебно у писмима Зелића, који је 1811. г. напустио своју функцију и повукао се у манастир у Крупи.

12 Посебно је солидна, на пример, размена писама са Виченцом Дандолом (Vincenzo Dandolo, 1758-1819), венецијанским патрицијем ког је био гувернера Далмације од 1806. до 1809. године. Преписка између Зелића и Дандола чува се углавном у ДАЗД-у.

${ }^{13}$ Што се тиче Краљевићеве личности, немамо много информација: Никодим Милаш, на пример, ослања се готово искључиво на Зелићево Житиије, јер како и сам признаје не располаже другим изворима (20043: 469). Много поузданије су у том смислу студије Љубомира Влачића и Персиде Лазаревић Ди Ђакомо на које упућујем за више информација. 
Осим писама двојице свештеника - изворних докумената у Краљевићевом случају, и копија у Зелићевом - међу рукописе који припадају овом првом тематском језгру убрајају се и молбе које су представници српских заједница из северне Далмације упућивали аустријским властима тражећи да се Краљевић удаљи из регије због своје блискости с унијатском црквом. Уистину, у освит друге аустријске владавине у Далмацији бечким властима се поново појавио проблем православаца: аустријски двор је планирао да их доведе под окриље Католичке цркве још од 1804, пројекат чија је мотивација била јасно политичка пошто би омогућила да се заустави руски утицај на Балкану; долазак Француза је, међутим, прекинуо планове Беча. Године 1815. са̂м цар Франц I преузео је руковођење иницијативом отварајући пут „првом таласу систематског ширења унијаћења код православаца у Далмацији“ који је Персида Лазаревић ди Ђакомо (2007: 183) описала као „најзначајнији друштвени и културни догађај међу Србима у Далмацији прве половине 19. столећа“.

Зелић, ког су аустријске власти описивале као „еin feiner intriganter Geistlicher" (ВлАчић 1935: 65), одлучио је да их предухитри. Већ у септембру 1814. г. послао је Францу I меморандум у којем је оптуживао Краљевића да је на страни Француза, те да се упрљао симонијом током свог мандата. Приморан да брани свој положај, Краљевић је у тајности изразио своју спремност да прихвати верску политику Аустријанаца, представљајући цару предлог за оснивање грчко-католичког семинара са седиштем у Шибенику. Крајем 1819. из Галиције су кренула четири унијатска учитеља да преузму службу међу Србима у Далмацији: међутим, стигавши на лице места били су приморани да се суоче с незадовољством локалне заједнице, свесне Краљевићеве издаје а уз подршку самог Зелића, који је у међувремену повратио популарност и наговарао своје сународнике да се подигну против његовог ривала. Због лакоће којом је усвојио верску политику Беча, Краљевић је постао „најомраженији човек међу Србима с обале“, толико да је био предмет атентата који је на своју срећу успео да избегне. ${ }^{14} \mathrm{Ca}$ друге стране, Зелић је био оптужен за клевету и принуђен од стране аустријских власти на напусти свој манастир и Далмацију, где се више неће вратити: био је прогнан најпре у Беч, потом у Будим где је остао до своје смрти (1828) покушавајући ипак да на сваки начин поврати положај и врати се у родну Далмацију. О свим тим догађајима говоре нам документи сачувани у АСАНУК-у показујући како је сукоб два свештеника заузео средишње место не само у Зелићевој каријери, већ и у ширем контексту конфесионалне полемике у Далмацији.

Друго тематско језгро чини преписка између Герасима Зелића и карловачког митрополита Стефана Стратимировића (1757-1836). Осим што садржи највећи број докумената, та преписка је посебно занимљива пошто

${ }^{14}$ Краљевић је најпре побегао у Задар, а затим се преселио у Венецију где је живео још 40 година. Званично је умировљен тек 1828. г. (ЛАзАРЕВИЋ ди ЂАКОмо 2007: 184, белешка 6). 
описује, иако индиректно, прилике Српске православне цркве у Далмацији на прелазу између XVIII и XIX века. Такође, из писама двојице српских свештеника сазнајемо бројне детаље о формирању финансијског фонда у Карловачкој митрополији који је основао сада већ стар и на изгнанство принуђен Зелић: захваљујући том средству, десетине српских младића из далматинских заједница добили су могућност да студирају теологију у угледним установама сремскокарловачке вароши. Поред Зелићевих писама и писама митрополита Стратимировића, ово друго језгро чине и писма неких младих српских богослова далматинског порекла, међу којима и Алексеја Зелића, синовца српског архимандрита. Оснивачки акт фонда који је створио Зелић и књиговођствени регистри фондације, који до детаља приказују све трошкове до 1914. године, чувају се у ДАЗД-у.

Треће и последње тематско језгро обухвата документе везане за последњу фазу живота Герасима Зелића. Оптужен за клевету због неких писама у којима позива далматинске православце да се подигну против Краљевића, Зелић је био приморан да се удаљи из родне Далмације 1811. године и да своје последње године проведе у изгнанству, под сталним надзором аустријских власти. Ово треће језгро рукописа, дакле, садржи с једне стране дописе које је Зелић примао од аустријских власти, а с друге - молбе којима је српски архимандрит покушавао у више наврата да поврати свој положај и врати се у Далмацију, нажалост безуспешно. Највећи део молби, написаних превасходно на српском језику, али и на немачком, упућене су аустријском цару Францу I.

У последњем делу пројекта до сада цитирани рукописи упоређени су са документарном грађом садржаном у Зелићевом Жийију, како би се извукли неки закључци о улози коју документа имају у књижевном делу и начину на којих их је аутор обрадио. У циљу поређења, одлучили смо се за прво издање дела, објављено у Будимпешти 1823: тај избор је мотивисан чињеницом да је то издање, заправо, једино у којем су верно праћена ауторова упутства. Наиме, уредници наредних издања (1886, 1897-1900, 1988 - уп. Литература), довели су до знатног смањења документарног апарата, који је често искључен из главног текста јер је (погрешно) сматран „сувишним“. У погледу обраде документарне грађе, поређење штампаног текста и рукописа̂ показало је како је Зелић пренео документе на српском језику увек у целости и потпуно верно изворнику. У случају докумената написаних на италијанском или немачком, српски свештеник је углавном давао само превод са не тако занемаривим непрецизностима приликом превођења на српски језик.

Коначно треба додати да је поређење књижевног текста и докумената показало да је Жийије Герасима Зелића уравнотежена синтеза између документарног елемента и фикције, сасвим у складу с тадашњим књижевним тенденцијама. Не изненађује онда што се у опису ових дела говорило о „факцијској прози“, односно о уметничкој прози заснованој на конкретним 
чињеницама (уп. ИвАновић 1999). То својство потиче из жеље аутора да задовољи укус публике, која је у мемоарима тражила веран извештај о великим историјским догађајима епохе, заједно са сасвим личном потребом да се оправда сопствено деловање у очима потомака. Ова тврдња је посебно истинита у случају догађаја везаних за конфесионалну полемику, због чега српски архимандрит покушава оправдати сопствене изборе позивајући се на историјски, званичан документ. Потрага за веродостојношћу постаје, дакле, један од главних елемената Зелићевог дела о којем се генерално говори као о једном од првих примера уметничко-документарне прозе модерне српске књижевности (уп. Грдинић 2003; Лето 2014).

\section{ИЗВОРИ И ЦИТИРАНА ЛИТЕРАТУРА}

ВлАчић, Љубомир. Борба архимандрита Зелића за епископску митру фатална по православну цркву у Далмацији. Гласник срииске йравославне йайријариије 14 (1928): 215-220.

ВлАчић, Љубомир. Конфинирање архимандрита Зелића у Бечу. Боі̄ословље 10/1 (1935): $64-72$.

Грдинић, Никола. Аутобиографија - проблеми проучавања. Зборник Майище срӣске за књижевности и језик LI/3 (2003): 665-674.

ЗЕлик, Герасим. Жийіе сирбчь Рожяеніе, восииийаніе, стиранстивованія и различна йо

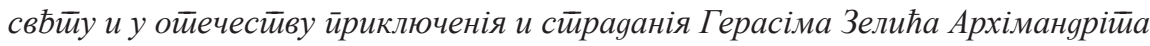
Светио-усиенске обители Круие у Далмаціи бывщеїа кое у исииой державы, кое у Бокки Койорской, оgъ л. 1796 gо кониа л. 1811. наgь ирравославными восйочноїа исйовбуанія иерквами / Нимъ самымъ Себи и своима за сииоменъ сииисано

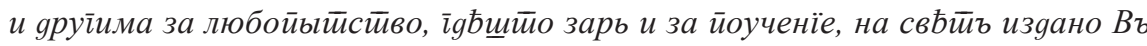
Буяимґ: Писмены Крал. Унїверсїиеейа Унїарскайо, 1823. Будим, 1823.

ЗЕлић, Герасим. Живой Герасима Зелића архимандрийа. Панчево: Наклада књижаре Браће Јовановића, 1888.

ЗЕлић, Герасим. Жийије Герасима Зелића. Beograd: СКЗ, 1897-1900.

ЗЕлик, Герасим. Жийије. Београд: Нолит, 1988.

Ивановић, Радомир. ‘Духа не угашајте!' (Семантика и морфологија Житија Герасима Зелића). Годищњак Филозофской факулиетеиа у Новом Саgу 27 (1999): 41-60.

ЈАчов, Марко. Венещија и Срби у Далмаџији у 18. веку. Београд: Историјски институт/ Просвета, 1984.

ЛАЗАРЕВић Ди ЂАКОмо, Персида. Венедикт Краљевић, историјски и литерарни чинилац трију животописа из Далмације (Г. Зелић, К. Цвијетковић, С. Алексијевић). Научни састианак славистиа у Вукове уане 36/2 (2007): 183-195.

ЛЕто, Марија Рита. Несаврщено мајсииорско дело: Досииеејево йремощћивање сииварносних и йрийовеgних іранииа. Београд: Задужбина „Доситеј Обрадовић“, 2014.

МилАш, Никодим. Православна Далмащија. Београд-Шибеник: Истина, 2004³ (1901). 
Младеновић, Александар. Славеносрйски језик: сийgије и чланщи. Нови Сад: Књижевна заједница Новог Сада; Горњи Милановац: Дечје новине, 1989.

\section{*}

Bogović, Mile. Katolička crkva i pravoslavlje u Dalmaciji za mletačke vladavine, Zagreb: Kršćanska sadašnjost, $1993^{2}$ (1982).

Fin, Monica, Han Steenwisk (a cura di). Gerasim Zelić e il suo tempo. Biblioteca di Studi Slavistici 44. Firenze: Firenze University Press, 2019.

Ivetic, Egidio. Cattolici e ortodossi nell'Adriatico orientale veneto, 1699-1797. Giuseppe Gullino, Egidio Ivetic (a cura di). Geografie confessionali: cattolici e ortodossi nel crepuscolo della Repubblica di Venezia (1718-1797), Milano: FrancoAngeli, 2009, $49-119$.

Morabito, Rosanna. Tradizione e innovazione linguistica nella cultura serba del XVIII secolo. Cassino: Laboratorio di comparatisica, Dipartimento di linguistica e letterature comparate, Università di Cassino, 2001.

Paladini, Filippo Maria. „Un caos che spaventa“. Poteri, territori e religioni di frontiera nella Dalmazia della tarda età veneta. Venezia: Marsilio, 2002.

RoKsandić, Drago. Triplex Confinium ili o granicama i regijama hrvatske povijesti, 15001800. Zagreb: BARBAT, 2003.

ŠARIĆ, Marko. Inter-confessional Relations and (In)tolerance among the Vlachs (16th-17th Centuries). Egidio Ivetić, Drago Roksandić (eds). Tolerance and Intolerance on the Triplex Confinium. Approaching the "Other" on the Borderlands. Eastern Adriatic and beyond, 1500-1800. Padova: CLEUP, 2007, 181-194.

Monica Fin

\section{THE INTERCONFESSIONAL POLEMIC IN GERASIM ZELIĆ'S PRIVATE LETTERS}

\section{Summary}

The interconfessional polemic which engulfed the Serbian Orthodox community living in the Dalmatian area close to the Triplex Confinium between the $17^{\text {th }}$ and $19^{\text {th }}$ century is a matter that has been intensively studied by historians, although with considerable differences regarding approach and results. The present paper summarizes the activities and the results of a research project dedicated to the personal and public fate of Gerasim Zelić (1758-1828), who as Vicar General of the Serbs of Dalmatia (1796-1810) was one of the main protagonists of the confessional polemic in Dalmatia. Firstly, the paper describes the activities which were carried out during the project, particularly the digitalization and on-line publication of a corpus of manuscript documents connected to Zelić. Secondly, it presents the results of a historical and culturological analysis conducted 
on the aforementioned documents, which have helped to clarify some unresolved questions pertaining Zelić's actual involvement in the events related to the confessional question in Dalmatia.

Dipartimento di Studi linguistici e letterari (DiSLL)

Università degli Studi di Padova

Via Elisabetta Vendramini, 13

35137 Padova (PD)

Italia

monica.fin@unipd.it 